Nadwa : Jurnal Pendidikan Islam

Vol. 12, Nomor 1 Tahun 2018

Accredited by Ristekdikti based on Decree No. 51/E/KPT/2017

\title{
Menangkal Radikalisme Atas Nama Agama Melalui Pendidikan Islam Substantif
}

\author{
Nanang Hasan Susanto \\ IAIN Pekalongan \\ nananghasansusanto80@gmail.com
}

\begin{abstract}
.
The increase of Islamic radicalism in Indonesia are the fact on social reality in Indonesia at present day. Therefore it is necessary to trace the basic substance of Islamic education. Through literature study and descriptive analysis, this study concludes that Islamic radicalism can be prevent by understanding the basis fundamental of islamic education in the form of 3 main points, namely: First, not mistaken in interpreting the Holy Qur'an, Second, not be trapped in the formalization of religion. The efforts of religion groups to establish the Khilafah Islamiyah (Islamic Empire)which is often triggered violence's in making it happen are categorized as a trapped on the formalization of religion. Third, implement a religious life with Hanif, that is to implement a religious life with a right attitude, Sincere and passionate truth, in accordance with what is exemplified by Prophet Ibrahim as the father of monotheis, and in accordance with the content of QS Ar-Rum verse 30.
\end{abstract}

Keywords: Islamic Radicalism, Substantive Islamic education

\begin{abstract}
Abstrak.
Menguatnya gerakan Islam radikal merupakan fakta yang terjadi di Indonesia akhir-akhir ini. Oleh karena itu, diperlukan upaya untuk menelusuri substansi mendasar pendidikan Islam. Melalui studi pustaka dan analisis deskriptif, penelitian ini menawarkan sebuah gagasan, bahwa radikalisme atas nama agama dapat ditangkal dengan memahami substansi mendasar pendidikan agama Islam berupa 3 hal pokok, yakni Pertama, tidak salah dalam menafsirkan kitab suci Al-Qur'an. Kedua, tidak terjebak pada formalisasi agama. Upaya berbagai kelompok untuk mendirikan Khilafah Islamiyah yang seringkali disertai kekerasan dalam mewujudkannya, dikategorikan sebagai bentuk keterjebakan pada formalisasi agama. Ketiga, menjalankan kehidupan beragama dengan hanif, yakni menjalankan kehidupan beragama dengan sikap yang lurus, tulus dan bersemangat kebenaran, sesuai dengan apa yang dicontohkan Nabi Ibrahim sebagai bapak monotheis, dan sesuai dengan kandungan Q.S. ar-Rum ayat 30.
\end{abstract}

Kata Kunci: Gerakan Islam Radikal, pendidikan Islam Substantif

IS SN 1979-1739 (P) ; ISS N 2502-8057 (E)

(5) 2018 Nadwa : Jurnal Pendidikan Islam | UnN Walisongo.

Accredited by Ristekdikti based on Decres Na. $51 / E / K P T / 2017$

http://joumal.walisongo.ac.id/index.php/nadwa 
Klaim kalangan muslim yang dengan bangga mengatakan bahwa agamanya merupakan "rahmat bagi sekalian alam" akhirakhir ini mendapat tantangan dengan semakin meluasnya pemahaman Islam garis keras. Tidak hanya berhenti pada tataran pemahaman, konsep Islam radikal bahkan kerap dipertontonkan baik oleh ormas, kelompok maupun jaringan tertentu yang sudah tidak syak lagi menggunakan atribut-atribut dan jargon-jargon Islam, bahkan menglaim tindakannya tersebut sebagai ibadah.1

Aksi teror yang terjadi di Indonesia cukup banyak. Diantaranya yang mengagetkan karena daya ledaknya cukup besar adalah serangan bom di Kuningan, JW Marriot dan bom Bali. Sepanjang tahun 2016 saja, aksi teroris dapat diidentifikasi, yakni bom thamrin (14 Januari), penggagalan rencana teror di Surabaya (8 Juni), bom Mapolresta Surakarta (5 Juli), rencana aksi teror Batam (5 Agustus), aksi teror Gereja Medan (28 Agustus), aksi teror Gereja Samarinda (13 November), mengancam objek vital negara (23 November), rencana bom istana (10 Desember), aksi teror Solo (15 Desember), rencana peledakan di Bali (18 Desember). 2

Maraknya aksi teror di Indonesia sebagaimana yang disebutkan diatas membuat warna Islam Indonesia berubah dari Islam yang toleran dan penuh harmoni menjadi Islam konservatf, bahkan radikal. Perubahan Islam di Indonesia menuju konservatif dibahas cukup detil pada buku yang ditulis oleh Martin Van Bruinesen dkk, berjudul: Contemporary Development in Indonesian Islam Explaining the "Conservative Turn". Semangat utama yang disajikan dalam buku ini adalah sebuah kesimpulan, bahwa muslim Indonesia sedang bergerak menuju konservatif. Menurut Din Wahid yang mereview buku ini, kecenderungan konsevatisme tidak saja muncul dalam gerakan-gerakan Islam kontemporer yang lahir pasca Reformasi, tetapi juga merasuk ke

1Potensi pemahaman Islam radikal di Indonesia saat ini masih cukup tinggi hal ini disebabkan potensi eksklusivitas beragama yang tumbuh dari truth claim dalam kehidupan umat beragama belum proporsional, lebih jelas lihat dalam Agus Khunaifi, Potensi Eksklusivitas Pendidikan Islam di Indonesia, Jurnal Inspirasi, vol. 1, No. 2, Juli-Desember 2017

2www.rappler.com (diakses tangal 23-1-2017) 
dalam tubuh ormas Islam yang sudah mapan, seperti MUI dan Muhammadiyah.3

Selain aksi teror sebagaimana yang disebutkan diatas, asumsi berubahnya muslim Indonesia menuju konservatif bahkan cenderung radikal ditandai dengan lahirnya berbagai kelompok Islam yang memiliki kecenderungan gerakan radikal., atau minimal memiliki dan bahkan menyebarkan pemahaman eksklusif tentang Islam garis keras. Sebut saja kelompok Front Pembela Islam (FPI), Majlis Mujahidin Indonesia (MMI) Laskar Jihad (LJ) dan Jama'ah Ikhwanul Muslimin Indonesia (JAMI). Meskipun jumlah kelompok ini terbilang sedikit dengan jumlah penganut ormas Islam Indonesia seperti Nahdlatul Ulama (NU) dan Muhamadiyah, namun gerakan dan propaganda pemahaman radikal memberikan warna signifikan terhadap warna Islam Indonesia pada konteks kekinian (pasca lengsernya rezim orde baru). 4

Berbagai aksi teror dan gerakan radikal yang semakin lama semakin intens tersebut merupakan pukulan keras bagi kalangan muslim, karena dia berasal dari dalam internal muslim itu sendiri. Sementara kalangan humanis sekulers mengkritik agama sebagai penghalang bagi terwujudnya tatanan sosial yang beradab6, maka aksi-aksi kekerasan yang kerap dilakukan atas nama agama, baik

3 Din Wahid, Kembalinya Konservatisme Islam di Indonesia (Book Review buku Contemporary Development in Indonesian Islam Explaining the "Conservative Turn", Singapore: Institute of Southeast Asian Studies, 2013, pp. $240+$ xxxiv.), dalam jurnal Studia Islamika, Vol. 21 No.2, 2014

4 Ah. Muzaki, The Roots, Strategies and Popular Perception of Islamic Radicalism in Indonesia Journal of Indonesian Islam, Vol. 8, No. 1, Juni 2014, hal: $2-3$

5 Humanisme sekuler adalah salah satu hasil perkembangan abad ke-18, pencerahan rasionalisme, dan kebebasan pemikiran abad ke-19. Humanisme sekuler melakukan pemberontakan terhadap agama, karena mereka menganggap agama tidak bisa diharapkan untuk mengadvokasi masalah kemanusiaan, bahkan agama sering menimbulkan masalah kemanusiaan. (Lihat Abdurrahman Mas'ud, Menggagas Format Pendidikan Nondikotomik, Gama Media: Yogyakarta, 2002. Hlm. 130

6 Lihat misalnya Karl marx yang menuding agama sebagai candu yang meninabobokan masyarakat dari permasalahan sosial yang ada dihadapannya. Atau Novel Salman Rushdie dengan The Satanic Verses (ayat-ayat setannya) 
oleh kalangan teroris maupun ormas, kian memperparah tudingan tersebut.

Tanpa bermaksud terjebak pada apologetik dengan membantah tuduhan kalangan humanisme sekuler tersebut (karena idealnya memang tidak perlu dibantah, tapi cukup dijawab dengan sikap dan tindakan nyata), tulisan ini mencoba untuk mengafirmasikan kembali kepada kaum muslim mengenai warna pendidikan Islam yang secara substantif menolak kekerasan dalam bentuk apapun, karena sejatinya Islam itu membawa kedamaian dan rahmat bagi sekalian alam.

Tindakan radikalisme atas nama agama muncul sebagai akibat kegagalan dalam memahami esensi substantif pendidikan Islam. Tulisan ini akan mengelaborasi 3 hal pokok yang dapat dilakukan umat Islam agar mampu menangkap pendidikan Islam substantif. Pertama, Menjaga keseimbangan antara kajian tekstual dan kontekstual dalam memahami Al-Qur'an. Kedua, menghindari formalitas keagamaan yang dangkal. Ketiga, beragama dengan hanif.

\section{Menjaga keseimbangan antara kajian tekstual dan kontekstual dalam memahami Al-Qur'an}

Berbicara mengenai kesalahan dalam menafsirkan kitab suci Al-Qur'an, menarik untuk menyajikan pemikiran Abdul Muta'ali dalam makalah yang diterbitkan di Jurnal Islam Indonesia berjudul The Repercussion of Gramatically and Cultural Culpability of the Holy Qur'an Translation to Religious Harmony in Indonesia. Dalam jurnal itu,Muta'ali menyampaikan, bahwa ketidakharmonisan kehidupan beragama masyarakat, lahirnya pemahaman Islam garis, bahkan munculnya tindakan radikalisme atas nama agama (teroris), bisa ditimbulkan dari kesalahan dalam menafsirkan kitab suci Al-Qur'an terutama dari aspek gramatikal (susunan struktur kebahasaan, dalam hal ini Bahasa Arab), dan aspek budaya. Menurut Abdul Muta'ali terdapat 90 ayat dalam Al-Qur'an yang salah ditafsirkan, sehingga memunculkan pemahaman Islam yang salah. Ayat-ayat yang salah ditafsirkan tersebut umumnya membicarakan tentang pengertian Islam, berbagai isu tentang non muslim dan keburukan orang-orang kafir. Muta'ali berpendapat, berbagai 
kesalahan dalam menafsirkan kitab suci inilah yang menjadi dasar ideologi lahirnya Islam garis keras, bahkan memicu lahirnya tindakan radikalisme atas nama agama yang semakin banyak kita jumpai seiring dengan masuknya era reformasi.7

Menurut Muta'ali, kesalahan dalam menafsirkan kitab suci sehingga melahirkan pemahaman Islam garis keras ini disebabkan karena upaya penafsiran yang tidak mengindahkan aspek gramatikal dan budaya dimana bahasa itu berasal (baca: Bangsa Arab). Misalnya saja, ketika berbicara tentang orangorang musyrik, dan sebelumnya ada kata "Qaatil", kebanyakan ditafsirkan dengan "bunuhlah". Sehingga kalimat "Qaatilu almusyrikiina", selalu ditafsirkan dengan "bunuhlah orang-orang musyrik. Padahal, secara gramatikal menurut Muta'ali, kata Qaatilu diambil dari Qaatala yuqaatilu yang memiliki makna saling. Karena saling, maka lebih tepat ditafsirkan dengan berperang. (Mengingat kondisi saling membunuh terjadi pada situasi peperangan). Makna kata "bunuhlah", memiliki makna yang sangat berbeda dengan "berperanglah". Jika kata bunuhlah mengandung arti tindakan individual yang kejam, tribal dan primitif, kata "berperanglah" memiliki makna yang lebih manusiawi, mengingat kondisi budaya pada waktu itu yang tidak bisa menghindarkan diri dari peperangan. Meskipun begitu, dalam peperangan terdapat etika seperti tidak boleh merusak fasilitas sosial, tidak boleh membunuh wanita anak-anak, dan lain-lain.8

Selain itu, secara umum budaya Arab memaknai kata "kafir" sebagai menolak, mendustakan atau mengingkari. Misalnya dalam kalimat "Kaffarta hubbi", bisa diartikan "kamu telah menghianati cintaku". Tapi dalam bahasa Indonesia, kata "kafir" maknanya lebih dipertegas sebagai lawan kata dari mukmin. Sehingga, mengandung makna penghakiman kepada seseorang, yang bisa memicu terjadinya ketegangan antara agama yang berbeda, bahkan tindakan radikalisme atas nama agama. 9

7 Abdul Muta'ali, The Repercussion of Gramatically and Cultural Culpability of the Holy Qur'an Translation to Religious Harmony in Indonesi. Journal of Indonesian Islam, Vol. 8, o. 1, June 2014. Hal: 59-60.

8 Abdul Muta'ali, Ibid. Hal. 60-61.

9 Abdul Muta'ali, Ibid. Hal. 64 
Secara lebih rinci, Muta'ali menmberikan contoh beberapa kitab suci Al-Qur'an yang salah ditafsirkan. Misalnya saja, dalam Al-Qur'an Surat Al-Baqarah ayat 28 yang berbunyi:

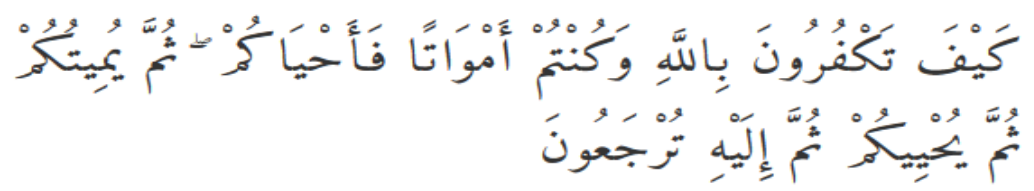

Di Indonesia, secara umum ayat ini ditafsirkan sebagai berikut:

"Mengapa kamu Kafir kepada Allah, padahal kamu tadinya mati, lalu Allah menghidupkan kamu, kemudian kamu dimatikan dan dihidupkan-Nya kembali, kemudian kepadaNya lah kamu dikembalikan”.

Menurut Muta'ali, penafsiran yang umum berkembang di Indonesia sebagaimana yang disebutkan diatas mengandung kesalahan fatal. Pertama, dari aspek gramatikal kata "takfuruna" tidak bisa ditafsirkan dengan kata "kafir". Hal ini dikarenakan kata takfuruna secara gramatikal Bahas Arab merupakan Fi'il Mudhori (kata kerja). Sedangkan kata "kafir" merupakan isim fa'il (subjek/ pelaku). Dalam teori translit, bahasa yang digunakan untuk menerjemah, sebaiknya menggunakan struktur morphologi yang sama dengan bahasa yang diterjemah. Kedua, dari aspek budaya. Sebagaimana disebutkan diatas, secara umum, budaya Bahasa Arab khususnya ketika Al-Qur'an diturunkan, kata "kafir" yang diambl dari suku kata "ka-fa-ro" dimaknai sebagai menolak, mengingkari, mendustakan dan sejenisnya. Sehingga, kata "takfuruna billahi" sebagaimana yang terdapat pada Al-Qur' an Surat Al-Baqarah ayat 28 diatas lebih tepat jika ditafsirkan: "Kamu mengingkari berbagai nikmat yang diberikan Allah".10

Terjemahan sebagaimana ditawarkan Muta'ali hemat penulis akan lebih serasi dan berpadu dengan isi kalimat sesudahnya, sehingga terjemah keseluruhan ayat tersebut menjadi "Mengapa kamu mengingkari berbagai nikmat yang diberikan Allah,

10 Abdul Muta'ali, Ibid. Hal. 63-64. 
padahal kamu tadinya mati, lalu Allah menghidupkan kamu, kemudian kamu dimatikan dan dihidupkan-Nya kembali, kemudian kepada-Nya lah kamu dikembalikan". Keserasian menafsirkan kata "takfuru" dengan kata "Катu mengingkari"lebih terasa dibandingkan dengan penafsiran "kamu kafir", mengingat kalimat sesudahnya adalah "padahal kamu tadiya mati, lalu Allah menghidupkan kamu, kemudian kamu dimatikan dan dihidupkan-Nya kembali, kemudian kepadaNya lah kamu dikembalikan". Dengan melihat kalimat penjelasan ini, menjadi mudah dipahami pesan ayat, bahwa tidak sepantasnya kita mengingkari berbagai nikmat yang diberikan Allah, karena Dialah yang menghidupkan dan mematikan kita, dan kepada-Nya lah kita kembali.

Salah satu contoh lain berupa kesalahan dalam menafsirkan kitab suci Al-Qur'an sebagaimana disampaikan Muta'ali, dapat ditemukan pada Al-Qur'an Surat Al-Baqarah ayat 191. Teks ayat tersebut berbunyi:

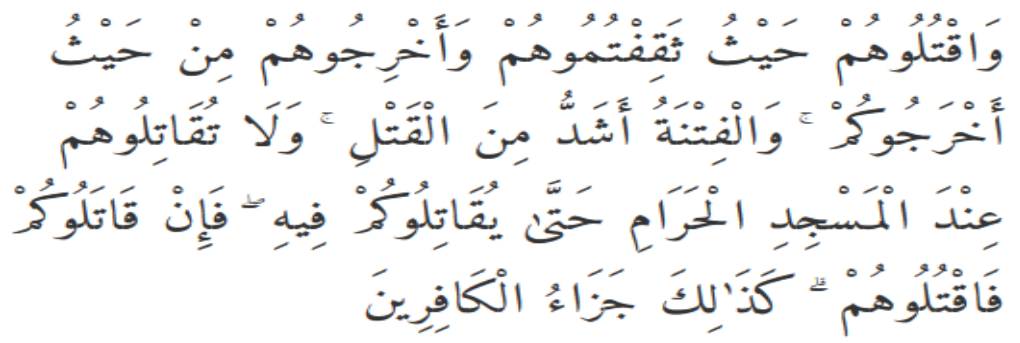

Secara umum, penafsiran yang beredar di Indonesia terhadap ayat ini adalah sebagai berikut:

"Dan bunuhlah mereka di mana saja kamu jumpai mereka, dan usirlah mereka dari tempat mereka telah mengusir kamu (Mekah); dan fitnah itu lebih besar bahayanya dari pembunuhan, dan janganlah kamu memerangi mereka di Masjidil Haram, kecuali jika mereka memerangi kamu di tempat itu. Jika mereka memerangi kamu (di tempat itu), maka bunuhlah mereka. Demikanlah balasan bagi orang-orang kafir". 
Menurut Muta'ali, kesalahan fatal dalam menafsirkan ayat ini terletak pada kalimat Waqtuluuhum haithu thaqiftumuuhum, yang diartikan dengan "Dan bunuhlah mereka di mana saja kamu jumpai mereka”. Menafsirkan kitab suci Al-Qur'an seperti ini tidak saja salah, tapi juga sangat berbahaya dan menjadi ancaman serius bagi keharmonisan kehidupan beragama, bahkan dapat melahirkan tindakan terorisme. Betapa tidak, pemahaman bahwa kita diperintahkan membunuh seseorang/ sekelompok orang yang tidak seiman dengan kita, dimanapun dan kapan pun, merupakan sebuah pemahaman yang sangat berbahaya, dan sangat berpotensi untuk melahirkan tindakan radikalisme atas nama agama.

Menurut Muta'ali kesalaan utama dalam menafsirkan ayat ini terletak pada kata "thaqiftumuuhum", yang diartikan dimana saja kamu jumpai mereka. Berdasarkan tata bahasa Arab,kata thaqiftumuuhum diambil dari akar kata tsa-qa-fa. Muta'ali yang mengutip Mujam al'Ain dan Lisan al-A'rab mengartikan thaqiftumuuhum dengan menyerang (to attack). Sehingga, menurut Abdul Muta'ali, akan lebih tepat apabila ayat ini diterjemahkan dengan "Dan bunuhlah orang-orang yang menyerang kamu".11

Penafsiran yang berbunyi "Dan bunuhlah mereka di mana saja kamu jumpai mereka”, memiliki makna yang jauh berbeda dengan kalimat "Dan bunuhlah orang-orang yang menyerang kamu". Sementara kalimat pertama memberi kesan agresif untuk membunuh siapapun orang yang tidak seiman dengan kita (the other), kalimat yang kedua memiliki pengertian, kaum beriman diperintahkan untuk melawan tindakan sewenang-wenang yang dilakukan oleh orang lain.

Berbagai kesalahan dalam menafsirkan kitab suci Al-Qur'an sebagaimana yang dikemukanan Abdul Muta'ali diatas menjadi penghalang utama bagi kehidupan pluralisme dan demokratisasi di Indonesia. Sebagaimana yang disampaikan oleh Nurcholis Madjid dan dikutip oleh Faisar Ananda Arfa, bahwa proses demokratisasi di Indonesia berbeda dengan yang terjadi di Eropa. Sementara di Eropa penguatan demokratisasi dilakukan dengan 
mengeliminir peran agama, Indonesia justru sebaliknya menguatkan demokratisasi melalui penguatan terhadap pemahaman agama. Karenanya, penghalang utama bagi penguatan demokratisasi itu adalah adanya saling kecurigaan antar pemeluk agama. Terminologi seperti "Islam ekstrimis" atau "Islam Teroris" dan term "Konspirasi Kristen Katholik" hanya akan merusak kehidupan pluralisme dan demokratisasi di Indonesia12. Berangkat dari pemikiran tersebut, para pemuka agama perlu meluruskan esensi pendidikan Islam secara substantif, sehingga dapat mewujudkan harmonisasi sosial.

\section{Menghindari formalitas keagamaan yang dangkal}

Pada sebuah kegiatan seminar yang dilaksanakan oleh Badan Nasional Penanggulangan Teroris (BNPT) pada tanggal 1 Mei 2011 di pesantren Al-Hikam Depok Jawa Barat, Kepala BNPT mengatakan, bahwa aksi terorisme pada 10 tahun terakhir cukup mengkhwatirkan. Hal ini disebabkan oleh meluasnya pemhaman Islam garis keras yang mayoritas menyasar kepada generasi muda yang memahami agama (dalam hal ini Islam) dengan cara instan, tidak mendalam dan komprehensif. Generasi muda banyak yang mempelajari Islam dari internet, serta sumber-sumber lain yan bukan naskah aslinya (edisi terjemah). Sedangkan makna yang tekandung dalam buku terjemah itu mengalami reduksi, karena didalam kegiatan terjemah, tidak dapat menghindarkan diri dari penafsiran-penafsiran sang penerjemah13.

Berawal dari bacaan yang tidak komprehensif terhadap ajaran agama, ditambah propaganda kelompok Islam radikal, bahwa umat Islam saat ini tertindas, didzolimi oleh orang-orang kafir seperti yang terjadi di Irak, Suriah, Palestina dll, hasilnya banyak kalangan anak muda yang tertarik dengan paham Islam radikal. Sebagaimana yang disampaikan oleh Wasisto Raharjo Jati, berawal dari perasaan ketertindasan yang dialami umat Islam

12 Faisar Ananda Arfa, Problems of Pluralism in Modern Indonesian Islam, Journal of Indonesian Islam, Volume 08, Nomor 02, Desember 2014, hal. 213

13 Ansyad Mbai, Gerakan NII, Penyebab dan Solusinya (makalah disampaikan pada Seminar Nasional yang dilasanakan di Pesanren Al-Hikam, Depok, Jawa Barat, (11 Mei 2011) 
tersebut, maka tujuan dari gerakan Islam radikal di dunia - tidak terkecuali Indonesia-, adalah untuk mendirikan Khilafah Islamiyah, sekaligus menegakkan terwujudnya hukum (Syari'ah) Islam.14

Pernyataan Raharjo Jati sesuai dengan fakta yang terjadi pada gerakan Islamic State of Iraq and Syria (ISIS) dibawah pimpinan Abu Bakar Al-baghdadi. Gerakan yang terkenal karena berbagai aksi terornya ini mendeklarasikan organisasi kelompoknya sebagai Khilafah Islamiyah, dan bercita-cita menegakkan hukum (Syari'ah) Islam. Abu Bakar Al-Baghdadi yang memproklamirkan diri sebagai khalifah (pemimpin), bahkan menyerukan kepada umat Islam di seluruh penjuru dunia, untuk bergabung dengan mereka di bawah bendera khilafah Islamiyah. Masyarakat yang tergiur dengan ajakan Abu Bakar Al-Baghdadi mayoritas termotivasi karena anggapan akan datangnya Imam mahdi sebagai pemimpin umat Islam yang mampu membawa Islam menuju kejayaannya. Selain itu, ISIS juga dianggap sebagai kelanjutan dari imperium Islam ottoman (Turki Usmani).15

Meski demikian, seruan Abu Bakar Al-Baghdadi ditolak oleh mayoritas umat Islam di seluruh dunia, khususnya dikalangan sarjana Islam. Mereka menganggap, Al-Baghdadi mengangkat dirinya sebagai khalifah secara sepihak, tanpa ada proses komunikasi dengan umat Islam diseluruh dunia, apalagi proses pemilihan sebagaimana yang dipercayai dalam konsep kepemimpinan di kalangan Sunni.16. Selain itu, menurut Makrum yang mengutip Taqiyuddin al-Nabhani, dalam tradisi Sunni, syarat bagi seorang khalifah adalah laki-laki, baligh (dewasa), cerdas, adil, merdeka, dan mampu menjalankan amanah sebagai khalifah. Menurut Makrum, Al-Baghdadi tidak memenuhi syarat sebagai khalifah seperti yang disebutkan diatas, terutama pada aspek al-'adalah (adil).Al-Nabhani yang dikutip Makrum juga

14 Wasisto Raharjo Jati, Radicalisme In the Perspective of Islamic Populism; Trajectory of Political Islam In Indonesia, Journal of Indonesian Islam, Vol. 7, No. 2, Desember, 2013, hal: 268

15 Makrum, Tracing the Historical and Ideological Roots of ISIS: Shi'ite or Sunni? Indonesian Journal of Islam and Muslim Societies, Volume 6, Number 2, December 2016 hal: 231-232

16 Ibid, hal. 234-235 
mengatakan, bahwa Khalifah harus berdasarkan kontrak politik (aturan atau undang-undang), yang terbentuk dalam iklim kebebasan berpendapat. Kontrak/ Undang-undang dimaksud akan menjadi ikatan kesetiaan warga untuk mematuhi seorang pemimpin, selama pemimpin tersebut masih setia terhadap Undang-undang. Apabila seseorang merebut kekuasaan dengan cara paksa dan kekerasan, dia tidak secara otomatis menjadi Khalifah, meskipun dia telah memproklamirkan diri sebagai seorang Khalifah dan mampu menjalankan amanah sebagai Khalifah.17

Apa yang dilakukan oleh ISIS dengan mendirikan Negara Islam (khilafah Islamiyah/ Daulah Islamiyah), melakukan teror di berbagai Negara, dan menganggap kafir Negara-negara yang mayoritas berpenduduk Muslim tapi tidak mau bergabung dengan mereka telah membuat citra negatif umat Islam di mata Internasional. Hal ini juga sesuai dengan ramalan John L. Esposito dalam bukunya The Islamic Threat: Myth or Reality?. Dalam buku tersebut, Esposito mengatakan, bahwa ketakutan masyarakat dunia terhadap kebangkitan Islam yang ditandai dengan gerakan Pan - Islamisme pasca berhasilnya revolusi Islam di Iran, masih dirasakan hingga saat ini. Esposito menggunakan istilah "Global Intifada" untuk menggambarkan gerakan revolusi Islam di dunia melalui semboyan "jihad".18

Gerakan ISIS dan kelompok-kelompok radikal lain yang berhasrat untuk mendirikan Negara Islam (khilafah Islamiyah), sejatinya merupakan gerakan Islam yang terjebak pada formalisasi agama. Untuk menangkalnya, kita perlu merenungkan lebih dalam mengenai substansi ajaran Islam itu sendiri. Substansi ajaran agama Islam adalah terwujudnya tatanan sosial yang damai, berkeadilan, produktif (memiliki etos kerja yang tinggi), penuh toleransi dan saling menghargai antara sesama. Sederhananya, beragama adalah untuk kesejahteraan dan kebahagiaan manusia, karena memang Tuhan tidak butuh apapun

17 Taqiyuddin al-Nabhani, dalam Makrum, Ibid, hal. 235-236

18 John L. Esposito, Ancaman Islam: Mitos atau Realitas?, translated by Alwiyah Abdurrahman dan MISSI fromThe Islamic Threat: Myth or Reality?, Ed. III, 1996, Bandung: Mizan, 200. 
dari makhluk-Nya, termasuk agama.19 Dengan demikian, ketertundukan manusia kepada Tuhan pun pada hakekatnya untuk kepentingan dan kebahagiaan manusia itu sendiri.20

Ketidakterjebakan pada aspek formalisasi agama dan semangat yang tinggi untuk lebih mengacu pada substansi agama menurut Abdurrahman Mas'ud akan mempertemukan antara citacita humanisme sekuler dan humanisme religius dalam menciptakan tatanan sosial yang diharapkan.21 Abdurrahman Mas'ud mengatakan:

Kalau kita bisa mengembalikan nilai kritis dan substansi dasar agama, seperti dalam nilai-nilai Islam al-adala (keadilan), almusawwah (egalitarian), asyuro (musyawarah), dan al-khurriatul Ikhtiyar (kebebasan memilih dalam konteks khifdul mal atau perlindungan harta, khifdul nafs (perlindungan jiwa), khifdul din (perlindungan agama), khifdul aql (perlindungan akal), dan khifdul nazl (perlindungan keturunan), niscaya tidak ada silang sengketa lagi antara humanisme religius dan sekuler" 22

Dengan kata lain, kalangan humanisme sekuler tidak akan mengkritik agama-agama yang terlembaga (organized religion) dalam hal ini khususnya Islam, apabila kalangan agamawan mampu menangkap pesan mendasar dari diturunkannya agama, yakni terbentuknya fitrah keagungan dan kemuliaan manusia, dan dengan sendirinya dari kumpulan pribadi yang tercerahkan tersebut, akan menciptakan tatanan sosial yang agung, mulia sekaligus bermartabat.

Sesuai dengan semangat nilai-nilai keberagamaan diatas, maka dalam konteks Islam, syari'at yang menjadi simbol hukum Islam harus diarahkan pada aspek kemaslahatan. Dalam hal ini, Ibn al-Qayyim al-jawziyyah mengatakan, bahwa setiap masalah yang keluar dari keadilan menuju kecurangan, dari kasih sayang menuju permusuhan, dari maslahat menuju kerusakan, dan dari kebijakan menuju kesewenang-wenangan, maka bukanlah syari'at.23. Selain itu, Izzudin Ibn Abd al-Salam juga mengatakan, bahwa segala pembebanan hukum Islam harus difokuskan atau

19 Menggunakan bahasa Abdurrahman Wahid, Tuhan Tidak Perlu Dibela 20 Lihat Q.S. Al-An'am : 104

21 Abdurrahman Mas'ud, op.cit. hlm. 133

22 Ibid, hlm. 134

23 Ibn al-Qayyim al-jawziyyah, I'lam al-Muwaqqi'in, juz III, hlm. 3 
dikembalikan untuk kemaslahatan umat manusia, baik di dunia maupun di akherat.24 Selain itu, Susanto mengatakan, bahwa secara filosofis, tujuan diturunkannya Islam adalah untuk menegakkan nilai-nilai kemanusiaan dan keadilan. 25

Namun pada kenyataannya, praktek keberagamaan masyarakat kita memang masih memisahkan antara pelaksanaan ritual agama dengan terbentuknya kesalehan pribadi dan kesalehan sosial. Sebagai contoh, pada pelaksanaan ibadah haji, jumlah jama'ah selalu meningkat dari tahun ke tahun. Bahkan, seorang muslim yang mendaftarkan diri sebagai peserta haji harus menunggu belasan tahun untuk diberangkatkan. Pada pelaksanaan pemberankatan pun diantar oleh tetangga, kerabat dan saudara, sampai menyewa mobil bis dan truck, diiringi dengan gema suara talbiyah. Namun, hal itu tidak berdampak pada tatanan sosial yang disemangati oleh nilai-nilai ke-Tuhanan, sebagaimana pesan universal yang terkandung dalam ibadah haji. Hal ini bisa dilihat pada praktek korupsi yang masih merajalela, budaya hedonis yang tidak berkurang, dan perhatian dari si kaya (aghniya) kepada si miskin (fuqoro), yang tidak lebih baik.

Contoh berikutnya bisa dilihat pada pelaksanaan ibadah puasa dan perayaan hari raya Idul Fitri. Menjelang dan pada saatnya tiba, hampir semua instansi mengucapkan selamat menunaikan ibadah puasa dan selamat hari raya idul fitri melalui spanduk-spanduk dan pamflet. Disiarkan di seluruh media, baik cetak maupun elektronik, sehingga terasa betul kalau kaum muslim sedang melaksanakan ibadah puasa. Tidak berhenti sampai disitu, acara-acara keagamaan bahkan sampai tayangan sholat tarawih berjama'ah disiarkan langsung dari masjidil haram. Dalam menyambut hari raya idul fitri, hampir semua kaum muslim menggunakan baju baru. Semua supermarket, toko pakaian dari yang besar sampai yang kecil penuh sesak oleh para pembeli, dan tidak jarang sampai kehabisan barang. Pun harga barang sudah dinaikkan berlipat-lipat. Tentu tidak ada yang salah

24 Izzudin Ibn Abd al-Salam, Qawa'id al-Ahkam fiy Mashalih al-Anam (Beirut: Dar al-jil, tanpa tahun), juz II hlm. 72

25 Nanang Hasan Susanto, Reinterpretasi Konsep Bidah Menuju Islam Transformatif. Madania: Jurnal Kajian Keislaman, Vol. 21, No. 2, 2017. Hal: 244,246 
dengan semua ini, karena disamping kegiatan keagamaan menjadi marak, juga kohesi sosial di dalam masyarakat menjadi baik. Akan tetapi akan jauh lebih indah lagi, kalau semuanya berdampak pada substansi mendasar tujuan diadakannya ritual keagamaan tersebut, yakni kembalinya manusia kepada fitrah ('Id al-Fithr) yang mengenal identitas dan jatidirinya sebagai makhluk yang berketuhanan26. Yakni makhluk yang mendasarkan segala perbuatannya sebagai pengabdian kepada Tuhan, karena memang tidak bisa melepaskan dirinya dari Tuhan yang menjadi sumber dan penentu kebahagiaan.

Fenomena masih terjebaknya sebagian kaum muslim pada formalisasi agama juga dapat dilihat pada maraknya ceramah agama, baik di media (cetak maupun elektronik), maupun di kalangan masyarakat muslim baik ketika hajatan, tasyakuran, Peringatan Hari Besar Islam (PHBI), dan lain-lain. Disamping mayoritas penceramah terjebak pada penyampaian ajaran agama yang tekstual dan verbal, indikasi formalisasi agama pada kegiatan ini dapat terlihat dari kurang berdampaknya kegiatan ceramah agama itu pada bentuk masyarakat sesuai dengan yang diinginkan Islam. Hal ini terbukti pada tingkat stress masyarakat meningkat, angka kriminalitas yang tidak berkurang, produktifitas dan kreatifitas masyarakat yang tidak kunjung membaik, bahkan kekerasan atas nama agama kian memprihatinkan.

Padahal secara substantif, nilai-nilai Islam tidak terlepas dari terwujudnya kemaslahatan sosial. Di dalam Al-Qur'an, kata Iman selalu diikuti dengan amal shaleh27. Lebih dari itu, semua ajaran dalam Islam tidak terlepas dari terwujudnya kesalehan individu dan kemaslahatan sosial. Dalam Syahadat, terkandung semangat tauhid yang membebaskan manusia dari penghambaan dan ketertundukan palsu. Baik kepada benda, atasan, penguasa, jabatan, atau apapun. Disamping itu, tauhid yang menjadi inti syahadat juga berimplikasi pada sikap yang mendasarkan segala

26 Lihat Q.S al-Imran (3):79. Disini secara spesifik, Al-Qur'an menegaskan bahwa misi para utusan Allah (baca: Rasul) adalah mendidik masyarakat agar menjadi kaum yang berkesadaran ketuhanan (rabbaaniyun)

27 Lihat Q.S al-Kahfi (18): 107-108, an-Nahl (16): 97, al-Ashr (103): 13, dan at-Tin (95): 6 . 
perbuaatannya untuk mencari ridlo Tuhan. Sehingga apabila dimaknai dengan benar, disamping akan mengantarkan manusia pada puncak kemuliaannya karena terbebas dari rasa takut dan ketergantungan terhadap apapun selain Allah, pemahaman terhadap syahadat juga akan mewujudkan kemaslahatan sosial, dengan terwujudnya sikap aman, damai, toleran, produktif, kreatif, inovatif dan sifat-sifat positif lainnya.

Sholat akan membentuk pribadi dan masyarakat muslim yang berdisiplin terhadap waktu, istiqomah (konsisten), dan memiliki kelapangan jiwa, karena lima kali dalam sehari kaum muslim menyerahkan hidup dan jiwa raganya kepada Allah swt, Sang Pemilik Kehidupan. Sholat dapat digunakan sebagai wahana bagi kaum Muslim untuk mengobati rasa rindunya kepada Allah swt. Disamping membentuk kesalehan individu, didalam sholat juga seharusnya dapat membentuk pribadi muslim yang memiliki kesalehan sosial. Hal ini dilambangkan dengan ucapan salam dengan menengok ke kanan dan ke kiri pada setiap akhir pelaksanaan sholat. Makna yang dapat diambil adalah bahwa setelah kaum muslim mendapat ketenangan jiwa dan kekayaan spiritual melalui sholat, maka tugas selanjutnya sebagai rangkaian yang tidak bisa dipisahkan adalah menebarkan kebaikan, kedamaian dan keselamatan kepada lingkungan sekitarnya. Seorang muslim yang baik tidak akan menyakiti orang lain baik dengan kata-kata maupun perbuatannya, keberadaannya bahkan menjadi rahmat dan embun penyejuk, minimal bagi lingkungan sekitar terdekatnya.

Ibadah Zakat esensinya adalah ibadah sosial. Karena dia mensyaratkan seorang Muslim (Muzakki) untuk merelakan sebagian harta yang dimilikinya untuk diserahkan kepada orang yang berhak menerima zakat (mustahiq). Keikhlasan melaksanakan ibadah ini -sebagai tanda diterimanya ibadah --, membutuhkan kepekaan dan kepedulian sosial kepada orangorang yang nasibnya kurang beruntung. Dengan kata lain, disamping membentuk kesalehan individu, dengan melapangkan hati melalui berbagi, Zakat juga dapat membentuk kesalehan sosial dengan melatih kepekaan sosial, sehingga diharapkan dapat terwujud sebuah tatanan sosial yang saling berbagi, saling memiliki, dan penuh dengan semangat persaudaraan. 
Dalam ibadah Puasa, kaum Muslim dilatih untuk mengendalikan hawa nafsu. Jika dijalani dengan sungguhsungguh, tentu saja ini sangat berdampak terhadap pembentukan kesalehan individu, karena pengendalian diri merupakan salah satu modal utama dalam menjalani hidup. Disamping itu, puasa juga dapat membentuk kesalehan sosial, karena dengan berpuasa disamping kaum muslim dilatih untuk tidak mengucapkan katakata kotor dan menyinggung apalagi menyakiti orang lain, melalui puasa kaum muslim juga dilatih untuk memiliki kepekaan terhadap saudara-saudaranya yang kurang beruntung dan sering merasakan lapar karena kesulitan ekonomi yang menderanya.

Ibadah Haji mengajarkan kepada kaum muslim tentang nilainilai universal berupa persatuan, persaudaraan dan pandangan dunia yang monoteistik. Dimulai dari mikat makani, kaum muslim diharuskan melepas seluruh pakaian yang menjadi simbol status sosialnya, sekaligus melepaskan pengaruhpengaruh psikologis dari pakaian yang dikenakan dan menggantinya dengan pakaian Ihram yang serba putih melambangkan persamaan semua kedudukan manusia dihadapan Allah swt. Menurut Ali Syari'ati, Haji merupakan drama simbolik filsafat penciptaan anak-cucu Adam. Sedangkan esensi ritual haji adalah evolusi eksistensial manusia menuju Allah28.

Melalui $S a$ 'i, jama'ah Haji diajarkan tentang kisah Siti Hajar yang dengan tegar ditinggalkan suaminya di sebuah padang tandus dan gersang. Keimanan dan kepasrahan meyakinkannya bahwa Allah tidak akan mengabaikannya. Meskipun begitu, ia tetap berikhtiar mencari air dengan berlari-lari kecil ( $\left.S a^{\prime} i\right)$ dari bukit shafa - yang berarti suci, melambangkan kalau kita memulai aktifitas harus dimulai dengan hati yang suci - ke bukit marwa. Tatkala kebingungan mulai mendera, karena usahanya tak kunjung berhasil, pertolongan Tuhan pun datang dengan terbukanya mata air zam-zam dari tendangan bayi Isma'il yang menangis meronta-ronta karena kehausan. Peristiwa ini mengajarkan kepada kita, bahwa apabila kita telah menempuh hlm. 45

28 Ali Syari'ati, Haji (Bandung: Pustaka, 1995), terj. Anas Mahyudin, 
berbagai ikhtiar namun menemui jalan buntu, maka janganlah patah semangat. Karena Allah tidak akan mengabaikan kita29.

Melalui Thawaf, jama'ah haji diajarkan untuk terus bergerak satu arah menuju Allah. Menuju kesempurnaan, kebaikan, keindahan, kekuatan, pengetahuan, dan nilai absolut30. Hal ini melambangkan progresifitas, mobilitas dinamisnya seorang muslim yang harus terus bergerak menuju kesempurnaan, meskipun tidak akan bisa menjadi sempurna. Disamping itu Thawaf mengajarkan pandangan monoteisme kepada jama'ah, untuk konsisten bergerak hanya menuju Allah, dan tidak mengalihkan pandangan dari-Nya. Sejauh mata memandang, tidak ada yang tampak, kecuali gelombang manusia berpakaian putih yang terus bergerak menuju Allah, dan mengagungkan asma-Nya.

Sekali lagi disini dapat dikatakan, bahwa nilai-nilai dan ajaran Islam secara substantif tidak bisa dilepaskan dari misi sosial berupa kemaslahatan, kebahagiaan manusia lahir - batin, dunia akherat. Dengan paradigma berfikir seperti itu, maka keberadaannya sebagai rahmat bagi sekalian alam, tidak bisa dibantah oleh siapapun, termasuk oleh kalangan humanis sekuler. Paradigma berfikir seperti ini juga di dukung oleh Masdar F. Mas'udi dengan mengatakan, bahwa sejak awal, syari'ah Islam sebenarnya tidak memiliki basis (tujuan) lain kecuali "kemaslahatan manusia". Keterikatan yang berlebihan terhadap teks (nash), seperti dipromosikan oleh paham ortodoksi, telah membuat kemaslahatan hanya sebagai jargon kosong, dan syari'ah - yang pada mulanya adalah jalan - telah menjadi tujuan bagi dirinya sendiri31.

Kecenderungan pemahaman syari'ah yang literalis dan tektualis secara embrional bermula sejak masa-masa awal, yakni ketika beberapa sahabat termasuk Bilal bin Abi Rabah secara tegas menolak ijtihad Khalifah Umar dalam pembagian tanah $f a$ ' $i$ yang dikenal dengan sawad al-iraq. Ketika itu Khalifah Umar

29 Lihat.Q. S. al-Naml (27) : 62

30 Ali Syari'ati, Haji, op.cit, hlm. 56

31 Masdar F. Mas'udi Meletakkan Kembali Maslahat Sebagai Acuan Syari'ah, dalam Formalisasi Syari'at Islam di Indonesia(Jakarta, Renaisan), 200k, hlm. 223 
berpendapat, bahwa sejalan dengan jiwa syari'at, yakni kemaslahatan bagi umat manusia, harta rampasan berupa tanah yang subur itu tidak begitu saja dibagi habis kepada para tentara. Umar menawarkan (berijtihad), biarlah tanah taklukan itu tetap digarap oleh rakyat setempat, dengan ketentuan mereka harus membayar retribusi (kharaj) tertentu pada negara.

Ijtihad Umar yang berani dan cenerlang ini mendapat tantangan keras dari beberapa sahabat Nabi yang mendasarkan pendapatnya pada teks al-Qur'an32 dan sunah Nabi saw. Alasan lafzhuyah (tekstual) ini memang kuat. Tetapi dengan mengajukan alasan ma'nawiyah (substansial: maslahat), Umar merasa lebih kuat.

Aspek kemaslahatan sebagai tujuan mendasar dari ajaran Islam dapat dilihat dari sejarah, bahwa Nabi tidak pernah menerapkan hukum potong tangan secara mekanis, meskipun tertera dalam al-Qur'an. Abu Daud dan Nasa'i meriwayatkan bahwa waktu itu Abbad bin sharjil merasa sangat lapar, lalu masuk ke suatu kebun, dan mencuri buah-buahan, dan menyembunyikan hasil curiannya itu ke dalam bajunya. Pemilik kebun yang mengetahui perbuatan Abbad kemudian menangkap dan membuang pakaian yang berisi buah hasil curian, dan mengadukannya kepada Nabi. Dari pemaparan pemilik kebun, Nabi mengetahui kalau pencurinya adalah orang bodoh. Kemudian Nabi berkata: "Kamu tidak menasehatinya dan dia adalah orang yang kelaparan, dan kamu tidak memberinya makan". Sambil berkata demikian, Nabi bukan hanya mengembalikan pakaian Abbad, tapi juga memberinya makanan33.

Dalam kasus diatas, Nabi tidak menghukum pencurinya, malahan memberinya makanan dan mengecam kesombongan orang yang buahnya dicuri, dengan mengatakan "dia (pencuri) adalah orang bodoh yang kelaparan anda tidak memberinya makanan". Ini adalah sebuah simbol, pencuri mewakili sebuah masyarakat dimana kebodohan dan kelaparan merupakan sebuah penyakit masyarakat. Sedangkan pemilik kebun, yakni pemilik

32 Lihat Q.S al-Hasyr (59): 7

33 Asghar Ali Engineer, Islam dan Teologi Pembebasan, (terj). (Yogyakarta: Pustaka Pelajar) 2000, hlm. 258-259 
alat-alat produksi, mempunyai tugas untuk membagi-bagikan kelebihan hartanya34, untuk menciptakan keadilan sosial dan dan menghapuskan kelaparan dan kebodohan. Tentu saja kisah ini harus dipahami, bahwa Nabi sedang menyeru kepada manusia untuk terwujudnya tatanan kehidupan sosial yang berkeadilan.

Secara filosofis, kisah itu juga mengajarkan kepada kita bahwa menjadi kewajiban umat Islam untuk menjamin tercukupinya makanan dan menyediakan pendidikan, kesehatan sosial dan moral, sebelum memberikan hukuman kepada seorang pelanggar hukum yang mengganggu tatanan moral dan keadilan. Jika sudah terbangun masyarakat yang berkeadilan dan bermoral, siapa saja yang mengganggunya dengan kesombongan dan tindakan mencuri, pantaslah dijatuhi hukuman yang berat.

Pandangan bahwa Islam sebagai rahmat selanjutnya diberikan oleh Goenawan Muhamad yang mengutip pemikiran Nurcholis Madjid, bahwa kemenangan Islam tidaklah sama dengan kemenangan umat Islam, apalagi pribadi-pribadi. Kemenangan Islam adalah sebuah kemenangan ide, sebuah citacita, terserah siapa saja orangnya yang melaksanakan ide itu. Kemenangan Islam harus merupakan kebahagiaan bagi semua orang, malah semua makhluk. Kemenangan Islam tidak boleh diwujudkan dalam bentuk mengancam golongan lain35. Pandangan seperti ini merupakan bentuk konsekwensi dari penafsiran, bahwa Islam diartikan sebagai sikap tunduk, patuh, pasrah dan menyerah kepada Allah36.

Semangat untuk tidak terjebak pada formalisasi agama juga disuarakan oleh Marybeth T Acac. Dalam studinya yang berjudul Pancasila A Contemporary Application of Maqasid AlShari'ah?, Acac menyimpulkan, bahwa penerapan Pancasila dengan nilai-nilai Ketuhanan, Kemanusiaan, Persatuan, Musyawarah dan Keadilan Sosial, dalam konteks Maqasid Syari'ah (tujuan diberlakukannya hukum Islam) sesuai dengan hukum Islam (Fiqh). Kesimpulan tersebut ia hasilkan setelah menelusuri pandangan ulama klasik yang kapasitasnya keilmuan

34 Lihat Q.S. al-Baqarah (2): 15

35 Goenawan Muhammad dalam pengantar Nurcholish Madjid Pintupintu Menuju Tuhan, (Jakarta: Paramadina), 2002. Hlm. XIV

36 Lihat Q.S: Al-Baqarah (2):128, 131, 133 
keislamannya tidak diragukan seperti Al-Ghazali (W. $1111 \mathrm{M}$ ), Al-Shatibi (W. 1388), dan yang paling terkini adalah pandangan Al-Thahir Ibn. Ashur (W. 1973).37 Dengan lebih tegas, kamali bahkan mengatakan, bahwa melalui paradigma Maqasid AlShari'ah, Qiyas, Fatwa dan Ijtihad bisa dikesampingkan, apabila produk-produk hukum Islam tersebut tidak sesuai dengan tujuan utama diberlakukannya hukum Islam, yakni kemaslahatan umat manusia. 38

\section{Beragama dengan Hanif}

Selain tidak boleh salah dalam menafsirkan kitab suci AlQur'an dan tidak boleh terjebak pada formalisasi agama, keberadaan Islam sebagai rahmat, sehingga mampu menangkal gerakan radikalisme atas nama agama dapat terwujud apabila perilaku keagamaan umatnya dilakukan dengan hanif. Dalam alQur'an surat ar-Rum ayat 3039, kaum muslim diperintahkan untuk beragama dengan cara yang hanif. Para mufassir mayoritas menafsirkan makna hanif dalam ayat ini sebagai "lurus".

Kata hanif sendiri dalam al-Qur'an sering digandeng dengan kata muslim dan Nabi Ibrahim (Bapak monoteisme yang sangat dimuliakan dan menjadi tokoh tiga agama besar, yakni Yahudi, Nasrani dan Islam). Agama Nabi Ibrahim yang otentik dan asli itu disebut agama hanafiyah atau "ke-hanif-an", dan Nabi Ibrahim sendiri adalah seorang yang hanif, artinya bersemangat kebenaran, dan muslim, artinya bersemangat pasrah dan taat kepada Allah Tuhan Seru Sekalian Alam40.

Jika kalangan agamawan khususnya Muslim menjalankan agamanya dengan hanif, yang bisa diartikan sebagai sikap hidup yang lurus, tulus dan bersemangat pada kebenaran yang menjadi fitrah mendasar dari diciptakannya manusia (sesuai dengan

37Marybeth T Acac, Pancasila A Contemporary Application of Maqasid Al- Shari'ah?, Journal of Indonesian Islam, Vol 9, No. 1, June 2015. Hal. 5978

38Mohammad Hashim Kamali, Principles of Islamic Jurisprudence, 3rd rev. and enl. ed. (Cambridge, UK: Islamic Texts Society, 2003), p. 517.

39 Terjemahan singkat dari ayat tersebut kira-kira demikian :"Maka hadapkanlah wajahmu dengan lurus kepada agama Allah. Itulah fitrah dari Allah yang ditetapkan kepada manusia.

40 Nurcholish Madjid, op.cit, hlm. 55 
kandungan Q.S. ar-Rum ayat 30 diatas), dan sesuai dengan semangat tauhid yang dihembuskan oleh Nabi Ibrahim, maka niscaya kehidupan beragama khususnya Islam akan memperlihatkan warna aslinya yang sejuk, damai, toleran dan menjadi rahmat bagi sekalian alam.

Dalam hidup ini perbedaan merupakan sebuah keniscayaan yang tidak dapat dihindari. Baik perbedaan budaya, suku, agama, ras, golongan, warna kulit, jenis kelamin, dan sebagainya. Bahkan antar individu sekalipun yang satu budaya, suku, ras dan golongan terdapat banyak perbedaan, baik karakter, sikap, kecenderungan maupun pandangan-pandangan hidupnya. Perbedaan-perbedaan tersebut tidak jarang memicu terjadinya konflik, bahkan seringkali berupa perang antara kelompok, golongan, maupun antara agama. Sejarah telah menggoreskan tinta kelam perang antara agama yang panjang dan berlarutlarut41. Sungguh sebuah ironi, dikala agama diklaim oleh pemeluknya sebagai kebenaran dan jalan menuju Tuhan, tapi justru memicu peperangan yang bertendensi untuk menyakiti bahkan membunuh orang lain. Dan lebih ironi lagi dengan melihat alasan tindakan membunuh itu sebagai ibadah dan dilakukan atas nama kebenaran agamanya.

Untuk mengembalikan wibawa agama sebagai rahmat yang diturunkan Tuhan melalui utusan-Nya, pendidikan Islam secara substantif sangat dibutuhkan, yakni menuju peserta didik yang memiliki sikap yang hanif. Karena sikap yang lurus, tulus dan bersemangat kebenaran pasti akan berdampak pada suasana hati yang tenang, sejuk, damai sekaligus menyayangi orang lain. Sikap beragama yang hanif juga akan melihat perbedaan bukan sebagai sumber konflik melainkan rahmat42. Perbedaan akan dipandang sebagai kekayaan dan semakin meneguhkan ke-Maha Besaran Tuhan, sehingga justru mempertebal iman pada ke-Maha Kuasa-aan Allah swt.

${ }_{41}$ Lihat misalnya perang Salib yang berkepanjangan antara kaum Muslim dan Nasrani, atau tindakan teroris atas nama agama yang akhir-akhir ini banyak menghiasi media

42 Lihat Q.S. al-Hujarat (49): 13 


\section{Simpulan}

Secara substantif pendidikan Islam dapat tercapai, apabila pemeluknya melakukan tiga hal. Pertama, tidak salah dalam menafsirkan kitab suci Al-Qur'an, Menurut Abdul Muta'ali, kesalahan dalam menafsirkan kitab suci Al-Qur'an seringkali terjadi pada aspek gramatikal dan kurangnya pemahaman terhadap budaya Arab, sebagai bahasa dimana Al-Qur'an diturunkan. Kedua, beragama tidak boleh terjebak pada formalisasi agama. Upaya berbagai kelompok untuk mendirikan Khilafah Islamiyah sekaligus menegakkan syari'at Islam dikategorikan sebagai bentuk keterjebakan pada formalisasi agama. Padahal menurut Abdurrahman Mas'ud, secara substantif nila-nilai Islam yang pokok adalah ajaran mengenai al-adala (keadilan), al-musawwah (egalitarian), asyuro (musyawarah), alkhurriatul Ikhtiyar (kebebasan memilih dalam konteks khifdul mal atau perlindungan harta), khifdul nafs (perlindungan jiwa), khifdul din (perlindungan agama), khifdul 'aql (perlindungan akal), dan khifdul nazl (perlindungan keturunan). Ketiga, menjalankan kehidupan beragama dengan hanif, yakni menjalankan kehidupan beragama dengan sikap yang lurus, tulus dan bersemangat kebenaran, sesuai dengan apa yang dicontohkan Nabi Ibrahim sebagai bapak Monotheis, dan sesuai dengan kandungan Q.S. ar-Rum ayat 30.

Apabila ketiga hal pokok yang menjadi substansi mendasar pendidikan Islam dilaksanakan oleh pemeluknya, maka akan mampu menangkal radikalisme atas nama agama, sekaligus mewujudkan visi Islam sebagai agama yang menjadi rahmat bagi sekalian alam.

\section{Daftar Pustaka}

Abd al-Salam, Izzudin Ibn, tt. Qawa'id al-Ahkam fiy Mashalih al-Anam Beirut: Dar al-jil, , juz II.

Ali Engineer, Asghar, 2000. Islam dan Teologi Pembebasan, (terj). Yogyakarta: Pustaka Pelajar

al-jawziyyah, Ibn al-Qayyim, tt. I'lam al-Muwaqqi'in, juz III. Ananda Arfa, Faisar, 2014. Problems of Pluralism in Modern Indonesian Islam, Journal of Indonesian Islam, Volume 08, Nomor 02, Desember 
F. Mas'udi, Masdar, ), 2000. Meletakkan Kembali Maslahat Sebagai Acuan Syari'ah, dalam Formalisasi Syari'at Islam di Indonesia, Jakarta, Renaisan

Hashim Kamali, Mohammad 2003. Principles of Islamic Jurisprudence, 3rd rev. and enl. ed. Cambridge, UK: Islamic Texts Society.

Khunaifi, Agus, "Potensi Eksklusivitas Pendidikan Islam di Indonesia”, Jurnal Inspirasi, vol. 1, No. 2 (2017)

L. Esposito, John, , 2000. Ancaman Islam: Mitos atau Realitas?, translated by Alwiyah Abdurrahman dan MISSI fromThe Islamic Threat: Myth or Reality?, Ed. III, 1996, Bandung: Mizan.

Makrum, 2016. Tracing the Historical and Ideological Roots of ISIS: Shi'ite or Sunni? Indonesian Journal of Islam and Muslim Societies, Volume 6, Number 2, December

Mas'ud, Abdurrahman , 2002. Menggagas Format Pendidikan Nondikotomik, Gama Media: Yogyakarta.

Mbai, Ansyad . Gerakan NII, Penyebab dan Solusinya (makalah disampaikan pada Seminar Nasional yang dilasanakan di Pesanren Al-Hikam, Depok, Jawa Barat, (11 Mei 2011)

Muhammad Goenawan 2002. dalam pengantar Nurcholish Madjid Pintu-pintu Menuju Tuhan, Jakarta: Paramadina, Muta'ali, Abdul, 2014. The Repercussion of Gramatically and Cultural Culpability of the Holy Qur'an Translation to Religious Harmony in Indonesi. Journal of Indonesian Islam, Vol. 8, o. 1, June .

Muzaki, Ahmad, 2014. The Roots, Strategies and Popular Perception of Islamic Radicalism in Indonesia Journal of Indonesian Islam, Vol. 8, No. 1, Juni.

Raharjo Jati, Wasisto. 2013. Radicalisme In the Perspective of Islamic - Populism; Trajectory of Political Islam In Indonesia, Journal of Indonesian Islam, Vol. 7, No. 2, Desember.

Susanto, Nanang Hasan. 2017 Reinterpretasi Konsep Bidah Menuju Islam Transformatif. Madania: Jurnal Kajian Keislaman, Vol. 21, No. 2, Desember.

Syari'ati, Ali. Haji, 1995. Bandung: Pustaka, terj. Anas Mahyudin. 
T Acac, Marybeth, 2015. Pancasila A Contemporary Application of Maqasid Al-Shari'ah?, Journal of Indonesian Islam, Vol 9, No. 1.

Wahid, Din , 2014. Kembalinya Konservatisme Islam di Indonesia (Book Review buku Contemporary Development in Indonesian Islam Explaining the "Conservative Turn", Singapore: Institute of Southeast Asian Studies, 2013, pp. $240+$ xxxiv.), dalam jurnal Studia Islamika, Vol. 21 No.2.

Www.rappler.com (diakses tangal 23-1-2017) 